\title{
IRACEMA, LÚCIA E AURÉLIA: TRÊS PERSONAGENS FEMININAS SOB O OLHAR DE UM ESCRITOR ROMÂNTICO ${ }^{1}$
}

\author{
COSTA, Sueli Silva Gorricho ${ }^{2}$ \\ FRAGA, Nilce Ramos da Silva ${ }^{3}$ \\ SILVA, Paula Nascimento Forcinetti ${ }^{3}$
}

Recebido em: 2009-03-12

Aprovado em: 2009-09-28

ISSUE DOI: $10.3738 / 1982.2278 .179$

RESUMO: O trabalho propõe uma reflexão sobre as personagens femininas: Iracema, Lúcia e Aurélia, das respectivas obras de José de Alencar: Iracema (1865), Lucíola (1862) e Senhora (1875), do período literário do romantismo brasileiro. Procura-se enfatizar o papel do feminino dentro da sociedade da época, em que pouca voz a mulher tinha, mas a sua força e sua decisão já eram norteadoras dos seus sonhos e renúncias. Para compreender todo esse contexto, busca-se na Literatura Brasileira, especificamente, no período romântico, leituras de autores consagrados e comentários que possam ajudar a compreender o universo feminino. Será aplicado um questionário claro e objetivo, com perguntas dissertativas para alguns alunos do curso de Letras da FFCLItuverava e leitores das obras em estudo.

Palavras-chave: Literatura. Perfis femininos. Romantismo.

SUMMARY: This work proposes a reflection about three female characters: Iracema, Lúcia and Aurélia, from José de Alencar's literary compositions Iracema (1865), Lucíola (1862) and, Senhora (1875), respectively, from Literary Period of Brazilian Romanticism. This research tries to show the role of feminism inside the society at that time, in which woman had a little importance, but her strength and her decision guided her dreams and abnegations. To comprehend this context, we bring in Brazilian Literature, specifically in Literature Period of Romanticism, some readings of recognized authors that can help us to understand the feminine universe. We apply an explicit and objective questionnaire with dissertative questions to some students from Letras Course from FFCL-Ituverava and readers from literary compositions that are been studied.

Keywords: Literature. Female Profiles. Romanticismo.

\section{INTRODUÇÃO}

No século XIX, a ascensão da burguesia e o advento do Romantismo proporcionaram ao homem a consciência de sua individualidade, valorizando suas emoções e seus sentimentos, e abriram caminho à formação de um novo público leitor constituído por jovens e mulheres, anteriormente alheios à prática da leitura.

\footnotetext{
${ }^{1}$ Parte do Trabalho de Conclusão de Curso (Letras) apresentado à FFCL Ituverava- SP.

${ }^{2}$ Prof. ${ }^{a}$ Ms. da Faculdade de Filosofia Ciências e Letras de Ituverava / Fundação Educacional de Ituverava. Orientadora do TCC. Rua Cel. Flauzino Barbosa Sandoval, 1259, CEP 14500-000, Ituverava-SP. E-mail: sueligorricho@bol.com.br

${ }^{3}$ Graduada do curso de Letras da Faculdade de Filosofia Ciências e Letras de Ituverava / Fundação Educacional de Ituverava.
} 
A época, os sentimentos e as emoções do homem sempre estiveram presentes nas obras literárias, representados por personagens possuidores de características marcantes que expressam o estilo do autor que os criou.

O presente trabalho propõe uma reflexão sobre as personagens femininas: Iracema, Lúcia e Aurélia, das respectivas obras de José de Alencar: Iracema (1865), Lucíola (1862) e Senhora (1875) pertencentes ao período literário do Romantismo brasileiro e, em seguida, procura enfatizar o papel feminino dentro da sociedade da época, em que pouca voz a mulher tinha.

O autor José de Alencar, ao ter como objeto de criação as personagens femininas Iracema, Lúcia e Aurélia, trabalha com maestria para delineá-las numa visão dinâmica e diversa, e mostra que o comportamento dessas personagens não se limita ao de mulheres idealizadas para os padrões morais e intelectuais daquela época, muito menos com os valores presentes nas famílias patriarcalistas.

A ordem dos perfis a serem trabalhados segue em primeiro lugar com Iracema, a virgem dos lábios de mel; em segundo, Lúcia, mulher independente, dona de suas vontades e de seu corpo; e em terceiro, Aurélia, independente nas relações amorosas e financeiras.

Para entender todo esse contexto, busca-se compreender até que ponto três histórias diferentes, com três perfis femininos, também diferentes, sob o olhar romântico de José de Alencar, dialogam, entre si, com os valores sociais e morais da época e o quanto limitam as características de mulheres idealizadas, nas obras em que elas se destacaram.

Os procedimentos metodológicos, utilizados no trabalho para o estudo do tema em pauta, têm como fonte de dados, a revisão teórica por meio da interpretação dos referenciais bibliográficos, dos pressupostos teóricos, da análise do corpus, que consta de trechos sobre o perfil feminino das obras em questão. E, ainda, comentários sobre um questionário, aplicado pelas a alguns alunos do curso de Letras da FFCL-Ituverava, leitores das obras de José de Alencar, dando assim um caráter menos tendencioso e/ou subjetivo à análise.

Neste sentido, o objeto de estudo deste trabalho tratará da tipificação das personagens femininas presentes em três renomadas obras literárias e levará em conta o antagonismo presente em dois princípios: o bem e o mal, a mulher santa e a mulher satânica.

\section{A LITERATURA, O ROMANTISMO E O FEMININO}

A literatura, como toda arte, é uma transfiguração do real, é a realidade recriada através do espírito do artista e retransmitida através da língua para as formas, que são os gêneros, e com os quais ela toma corpo e nova realidade. Passa então, a viver outra vida, autônoma, independente do autor e da experiência de realidade de onde proveio. (COUTINHO, 2006) 
“[...] entendemos por literatura [...] fatos eminentemente associativos, obras e atitudes que exprimem certas relações dos homens entre si, e que, tomadas em conjunto, representam uma socialização dos seus impulsos íntimos.” (CANDIDO, 1980)

Assim, a literatura é uma criação, uma invenção que o autor utiliza para mostrar sua emoção a partir do contexto de sua atualidade, vista de um ângulo particular.

A literatura se faz presente nas grandes mudanças sociais e políticas, tem a peculiaridade de reinterpretar o mundo de acordo com as ações, gestos, palavras e sentimentos de uma sociedade que é a expressão do contexto histórico de uma época.

Pound (2007, p. 32) afirma que: "Literatura é linguagem carregada de significado".

A linguagem é uma das formas que os homens utilizam, desde os tempos mais remotos, para se comunicar, para se auto-afirmar, para nomear coisas e organizar o espaço em que vivem. Os autores usam a linguagem para significar e retratar situações de um povo, de uma pessoa ou de uma época.

A literatura é uma manifestação artística que difere das demais pela maneira como se expressa, pois, sua matéria prima é a palavra, a linguagem. O texto literário se caracteriza pelo predomínio da função poética.

Assim, "teve, portanto, o movimento literário romântico todas as qualidades de uma revolução, dando largas manifestações do temperamento poético e literário nacionais" (COUTINHO, 2002, p. 15).

O Romantismo surgiu nas últimas décadas do século XVIII com a burguesia moderna, classe que acreditava ser possível mudar os rumos de sua história. Os burgueses se opunham à Aristocracia. Essa é uma época de ruptura com os padrões existentes. Surge então a necessidade de buscar novos estilos, novas formas artísticas, novas idéias e também a busca de uma linguagem própria.

Para Guinsburg (1978, p. 14), “o Romantismo é um fato histórico e mais do que isso, é o fato histórico que assinala, na história da consciência humana, a relevância da consciência histórica."

Assim, cada povo tem a sua história e o homem romântico desenvolve essa consciência e o desejo de definir e documentar as expressões da identidade nacional, ou seja, a partir do historicismo romântico de partir, organizar e ordenar o tempo em etapas, períodos e idades.

Segundo Coutinho (2002, p. 4), “o Romantismo aparece como um amplo movimento internacional, unificado pela prevalência de caracteres estilísticos comuns aos escritores do período. É, portanto, um estilo artístico individual da época". 
Em vez de civilização, preferem pensar em cultura, isto é, nas particularidades de um povo ou de uma nação, seja na forma literária ou folclórica. Assim, o Romantismo é um movimento que se manifesta em diferentes formas nas artes, na música e principalmente na literatura.

“O romance romântico europeu foi, inicialmente, uma espécie de confissão pessoal, como que uma explosão da sensibilidade do indivíduo em face da sua nova circunstância histórica." (COUTINHO, 2002. p. 240).

No Brasil, o surgimento do Romantismo e de sua tendência nacionalista e historicista coincide com o momento em que as questões da construção da nova identidade nacional são discutidas, em razão da recente independência política. Para os brasileiros é a oportunidade de construir a própria historiografia, a nova identidade de um povo, que, até então, tem como referência a literatura lusitana.

Para Bosi (2000, p.14), "o assunto prioritário da geração de intelectuais ativos entre os anos da Independência e os meados do século XIX passava forçosamente pela construção da nova identidade nacional".

Nessa época, uma das fontes de inspiração dos brasileiros para fazer literatura está na natureza, no índio, nas questões políticas e sociais. Pois os poetas dessa época querem fazer uma literatura com temas nacionais.

Candido (1997, p.11) afirma que

\begin{abstract}
a independência [...] desenvolveu no romance e no teatro, o intuito patriótico [...], na mesma disposição profunda de dotar o Brasil de uma literatura equivalente à européia, que exprimisse de maneira adequada a sua realidade própria, ou como então se dizia uma literatura nacional.
\end{abstract}

No terreno da literatura, a vertente nacionalista do Romantismo brasileiro encontra no romance sua mais importante manifestação, dividindo o Brasil em três espaços - a cidade, o campo e a floresta, dando origem, respectivamente, aos romances urbano, regional e histórico-indianista. Nesse sentido, os escritores, em busca da "individualidade ideal", procuram documentar e descrever as especificidades da paisagem, do homem, da língua e da cultura nacionais como expressão do caráter nacional. (VENTURA, 1995)

Com a ascensão da burguesia acontece também a ascensão do romance, que encontra um público consumidor ávido por narrativas de amores difíceis e aventuras passageiras. Surge um novo público leitor: as mulheres e os jovens.

Dá-se então o aparecimento de um gênero literário novo no Brasil, o romance. Segundo Cereja; Magalhães (1995, p.152-153). 


\begin{abstract}
A palavra romance origina-se do termo medieval romanço, que designava as línguas usadas pelos povos sob o domínio do Império Romano. Essas línguas eram uma forma popular e evoluída do latim. Também se chamava romance às composições de cunho popular e folclórico, escritas nesse latim vulgar, em prosa ou em verso, que contavam histórias cheias de imaginação, fantasia e aventuras. Os romances se modificam de acordo com as transformações culturais. Somente em meados do século XVIII é que a palavra romance passou a designar o gênero como o entendemos hoje: um texto em prosa, normalmente longo, que possui vários núcleos narrativos em torno de um núcleo central. O romance, por relatar acontecimentos da vida comum e cotidiana, e por dar vazão ao gosto burguês pela fantasia e pela aventura, vem a ser o mais legítimo veículo de expressão artística dessa classe.
\end{abstract}

No Brasil, os romances publicados diariamente nos jornais, sob a forma de folhetins, são traduções de obras estrangeiras. O folhetim desaparece no século XX e o romance evolui. O primeiro romance brasileiro propriamente dito é O Filho do Pescador (1843), de Teixeira e Sousa, e A Moreninha (1844), de Joaquim Manuel de Macedo, é publicado no ano seguinte. "O romance romântico integra-se ao projeto nacionalista do Romantismo, esforçando-se por tematizar a realidade brasileira" (INFANTE, 2001, p. 244).

O romance romântico tem como eixo o respeito inicial pela realidade, manifesto principalmente na verossimilhança que procura imprimir na narrativa. O Nacionalismo é constituído da elaboração da realidade, do escrever sobre coisas locais, lugares, cenas fatos e costumes do Brasil.

No caso do indianismo, tratando-se de descrever populações de língua e costumes totalmente diversos dos portugueses, podia a convenção poética agir com grande liberdade, criando com certo requinte de fantasia a linguagem e atitude dos personagens (CANDIDO, 1997, p. 103).

No regionalismo exploram-se os costumes da época e da língua. Para Candido (1997, p.103) o modelo "dependia do esforço criador dos escritores daqui [...] O escritor oscilava entre a fantasia e a fidelidade ao observado [...] acabou por tornar artificial o gênero"

Como tendências do Romantismo brasileiro têm-se: o romance indianista, o romance regional, o romance urbano e o romance histórico. Contrapondo-se aos valores racionalistas e materialistas da sociedade burguesa, certos escritores do Romantismo criam uma literatura fantasiosa, identificada com um universo de satanismo, mistério, morte, sonho, loucura e degradação.

As contradições profundas do Romantismo encontraram neste gênero o veículo ideal. A emoção fácil e o refinamento perverso; a pressa das visões e o amor ao detalhe, os vínculos misteriosos, a simplificação dos caracteres, a incontinência verbal - tudo nele se fundiu, originando uma catadupa de obras do mais variado tipo, que vão do péssimo ao genial. (CANDIDO, 1997, p. 98)

Portanto, é dessas situações que surge o olhar, em especial, de José de Alencar, romântico que, segundo Candido (1997, p.104) acrescenta “à apresentação realista das relações sociais urbanas uma profundidade analítica [...], pressentida pelo Alencar de Senhora e Lucíola". 
"Dentre eles, três podem ser relidos à vontade e seu valor tenderá certamente a crescer para o leitor, à medida que a crítica souber assinalar a sua força criadora: Lucíola, Iracema e Senhora" (CANDIDO, 1997, p. 201). Essa citação mostra a importância dessas três obras de Alencar, que deixa claro que a cada leitura ou releitura, um novo olhar se delineia por entre as palavras, que vão sendo escritas, na construção de obras que instigam seus leitores a alçarem vôos cada vez mais profundos.

\section{IRACEMA}

Iracema é a índia que se apaixona pelo guerreiro branco, num romance em que a linguagem é muito poética e até ritmada. O nome Iracema é um anagrama da palavra América e também é construído a partir das palavras Ira (mel) e ceme (lábios), que resultou em Iracema, a virgem dos lábios de mel.

Candido (1997, p.200) fala que,

Iracema, em 1865, brota no limite da poesia, como o exemplar mais perfeito da obra poética na ficção romântica - realizando o ideal tão acariciado de integrar a expressão literária numa ordem mais plena de evocação plástica e musical. Música figurativa, ao gosto do tempo e do meio.

Alencar quis fazer uma homenagem ao Ceará, sua terra natal, contando a lenda de uma belíssima heroína indígena que renuncia à própria família e à própria tribo para viver seu grande amor proibido, junto a Martim. Este, durante uma caçada, afasta-se de Poti, seu amigo Potiguara e se perde na densa floresta que pertence aos Tabajaras. Ali conhece Iracema, por quem se apaixona. Como a índia era a virgem consagrada ao culto de Jurema, não podia ligarse a homem algum sob pena de morte. O amor foi maior que a lei e o medo. A fuga de Iracema com o homem branco ofende os chefes da tribo, que declaram guerra aos amigos de Martim. Iracema vê a derrota de seu povo, amarga a solidão e a insegurança com as prolongadas ausências do companheiro e, sofrendo muito, tem seu filho, a quem chama de Moacir, o filho da dor. A sobrevivência de Moacir, o homem do novo mundo, custa a vida de sua mãe.

Iracema é um dos romances da trilogia indianista de José de Alencar (O Guarani, Iracema, Ubirajara). É também conhecido como a lenda do Ceará, pois funde elementos da natureza com mitos indígenas. Sua narração é em terceira pessoa. A obra tem como foco o contato do índio com a civilização portuguesa e mostra sentimento de nacionalidade. $\mathrm{O}$ relacionamento de Iracema e Martim pode também mostrar o processo de conquista e valorização do país. 


\section{LUCÍOLA}

Maria da Glória, uma menina de catorze anos, durante a epidemia de febre amarela de 1850, vê toda a família cair doente e, para não deixá-la morrer da febre e da fome, deixa-se possuir pelo Couto, um vizinho que a possuiu em troca de dinheiro.

Segundo Candido (1997, p.207-208),

Em Lucíola, a situação é mais complexa, superando este jogo fácil de cordéis. A pureza da infância; o sacrifício da honra à saúde do pai, a brutalidade fria com que é violada, condicionam toda a vida de Lúcia. A lembrança de uma infância perdida é não apenas possibilidade permanente duma pureza futura, mas a própria razão de seu asco à prostituição. A luxúria do velho Couto, e mais tarde a prática do vício, torcem a personalidade de Lúcia.

Ao saber de onde viria a salvação de sua vida, o pai expulsa a filha de casa. Ela então é adotada por Jesuína e continua, de longe, à custa da venda do próprio corpo, sustentando seus entes queridos.

Lúcia, uma amiga de Maria da Glória, morre, e esta coloca o próprio nome no atestado de óbito assumindo o nome da companheira. Os pais de Maria da Glória são comunicados de sua morte e a perdoam. Mas a mais formosa, linda e rica cortesã do Rio de Janeiro, após viver dias e noites de orgias e prazeres, regenera-se. Apaixona-se por Paulo e abandona a vida que levava; no entanto, a mentalidade moralista da sociedade jamais admitiria que sua história tivesse um final feliz, ao lado de Paulo, cuidando da irmãzinha e criando o próprio filho. Assim, Lúcia engravida, mas tem complicações, nega-se a tirar do ventre o bebê morto, e em virtude disso, morre de complicações obstétricas.

Candido (1997, p.200) diz que: "Com Lucíola, onde se nota a marca da experiência teatral na firmeza do diálogo, o senso das situações reais e o gosto pelo conflito psicológico fazem deste, um dos três ou quatro livros realmente excelentes escritos por Alencar."

A personagem principal Lúcia é muito complexa, para ela a prostituição é um eterno tormento. Ela tem grande sentimento de culpa e acredita que somente ficaria limpa, de todo pecado que havia cometido, se morresse. Esse romance faz uma crítica social aos costumes da época. É considerado um romance urbano, pois fala do cotidiano e descreve a vida na cidade.

\section{SENHORA}

Aurélia Camargo, moça pobre que vive com a mãe viúva num bairro do Rio de Janeiro, apaixona-se por Fernando Seixas, que também se apaixona por ela, levando-os a pensar em casamento. Ambicioso por subir na vida a qualquer custo, esse rapaz elegante disfarça no luxo das aparências suas precárias condições econômicas a fim de impressionar 
possíveis moças casadoiras, que sejam donas de abonados dotes financeiros e, por isso Seixas troca Aurélia por Adelaide Amaral: por causa do seu suposto dote.

Coutinho (2002, p.262) fala que: "Em Senhora, que é um dos romances mais bem construídos do autor, realiza Alencar uma boa crítica à educação tradicional, ao casamento por conveniência.”.

Aurélia sente-se humilhada, desprezada e se enche de mágoas e raiva. Depois de receber uma fabulosa herança e enjoada do assédio interesseiro da maioria dos jovens pretendentes, resolve vingar-se de Fernando, por quem continua apaixonada, reconquistandoo com a mesma arma que o havia afastado dela, o dinheiro.

Para Candido (1997, p.208) "Em Senhora, a compra do ex-noivo pela menina pobre e humilhada, agora grande dama milionária, é um truque habilidoso de romancista de salão e, psicologicamente, profundo recurso de análise."

Fernando aceita a oferta do valioso dote oferecido por Lemos, para se casar com a misteriosa moça, que ele só conheceria depois de assinado o contrato. Após o casamento, a moça revela ao marido sua intenção de vingança que inclui a total abstenção de intimidade. A essa cena seguem-se dolorosos meses de humilhações, fingimentos, sarcasmos e hipocrisias. Após alguns meses, Fernando consegue reunir a quantia suficiente para recuperar a própria liberdade e dignidade.

A regeneração de Fernando e o perdão de Aurélia abrandam os ânimos e restauram o verdadeiro amor que sentiam um pelo outro.

A obra passa-se no Rio de Janeiro, fala do casamento por interesse, retrata a oposição de dinheiro e amor; mostra o choque entre o sentimento e o interesse econômico.

É considerado também um romance urbano, como em Lucíola, fala dos costumes da sociedade da época e relata o cotidiano e o conflito social entre o homem e a mulher.

\section{O AUTOR}

José Martiniano de Alencar, nascido no Ceará em 1829 e falecido no Rio de Janeiro em 1877, de tuberculose. Advogado, jornalista, político, escritor, teatrólogo. Seu pai é o senador José Martiniano de Alencar, ex - padre. Ainda criança, com onze anos, muda-se com a família para o Rio de Janeiro, onde freqüenta o Colégio de Instrução Elementar. Em 1844, Alencar vai para São Paulo e se matricula na Faculdade de Direito de São Paulo onde permanece até 1850. Quando termina o curso preparatório de Direito começa a advogar no Rio de Janeiro, colabora em vários jornais e dirige o Diário do Rio de Janeiro, onde divulga os seus primeiros romances (COUTINHO, 2002). 
Sua estréia como romancista acontece no Jornal Diário de São Paulo com o romance Cinco Minutos (1860) em forma de folhetins, o qual era publicado periodicamente despertando o interesse do leitor.

Candido (1997, p.200) diz que,

O desejo de escrever romance veio por duas etapas a José de Alencar. Aos quinze anos, em São Paulo, ainda estudante de preparatórios, lendo Chateaubriand, Dumas, Vigny, Balzac, imaginava um livro que fosse como os dos franceses, um "poema da vida real". Aos dezoito anos, viajando pelo Ceará e observando suas paisagens, sente o impulso de cantar a terra natal.

Alencar faz do romance um veículo para o conhecimento da terra e a consolidação do país como nação. Analisa e critica comportamentos, cria e dá vida a importantes símbolos da cultura brasileira; focaliza a época com criatividade e fantasia. Alarga os horizontes da língua portuguesa e cria uma linguagem literária brasileira. É um conservador na política e na moralidade, mas um revolucionário nas letras.

O seu estilo é basicamente poético. A paisagem e o mundo por ele mostrados são idealizados. A natureza surge diante do leitor mais como uma projeção imaginária da sua subjetividade do que um objeto de observação. Seus romances são frutos da sua experiência jornalística. Ao usar a observação da sociedade fluminense de seu tempo, Alencar cria histórias de intrigas, de namoros adolescentes, de lazer, de ansiedade, que giram em torno do dinheiro, do amor e da honra.

Para Candido (1997, p. 209), “Alencar foi [...] capaz de fazer literatura de boa qualidade tanto dentro do esquematismo psicológico quanto do senso da realidade humana."

Candido (2000, p.193) afirma que

Machado de Assis [...] foi, sob vários aspectos, continuador genial, não figura isolada e literariamente sem genealogia no Brasil, tendo encontrado em Alencar, além da sociologia da vida urbana, sugestões psicológicas muito acentuadas no sentido de pesquisa profunda [...]. Machado de Assis aprendeu com o admirado confrade amigo.

A vasta obra de Alencar é constituída por romances, poemas, peças teatrais, ensaios críticos e crônicas. Em relação à figura feminina na obra de Alencar Cademartori (1990, p.40) fala que:

Em relação à mulher, essa dicotomia fará com que surjam, nos textos românticos, a mulher santa assexuada e digna de amor, que será a mãe, a irmã e aquela que, com estas, possa ser assemelhada, e a mulher satânica, a que se dirige o desejo e cuja voluptuosidade torna ameaçadora e nociva. 
São perfis femininos, retratos de mulheres fantásticas que, ao mesmo tempo são delicadas e fortes, submissas e sedutoras.

"É, na realidade, um destino imposto à mulher [...] pela sociedade, pois a ela é ensinado que para ser aceita é preciso agradar, fazer-se objeto, portanto renunciar à sua autonomia" (LEITÃO, 1981, p.45)

Esses três perfis femininos, Iracema, Lúcia e Aurélia, não se deixaram dominar nem pelo meio, nem pela família. São mulheres que mesmo sob um olhar romântico, em uma época onde não se cogitava que a mulher tivesse o poder de decisão, apresentam outra postura, não são submissas ao sistema da sociedade vigente. Cada uma à sua maneira em busca de um ideal ultrapassa limites, barreiras e estabelece o seu próprio modo de ser, sua própria postura em busca de autonomia.

Leitão (1981, p.44) diz que "Outra característica marcante da personalidade feminina é a passividade. Logo, a mulher não pode ter iniciativa, porque esta é uma propriedade masculina."

Portanto, as mulheres referidas de Alencar fogem dessa passividade, pois elas têm atitude, iniciativa e consciência.

\begin{abstract}
Iracema, a virgem dos lábios de mel, que tinha os cabelos mais negros que a asa da graúna, e mais longos que seu talhe de palmeira. $\mathrm{O}$ favo do jati não era doce como seu sorriso; nem a baunilha recendia no bosque como seu hálito perfumado. Mais rápida que a ema selvagem, a morena virgem corria o sertão e as matas do Ipu, onde campeava sua guerreira tribo da grande nação tabajara. $\mathrm{O}$ pé grácil e nu, mal roçando, alisava apenas a verde pelúcia que vestia a Terra com as primeiras águas. (ALENCAR, 1999, p.5)
\end{abstract}

Nesse fragmento há uma descrição da mulher indígena. Alencar idealiza Iracema tornando-a sempre melhor, usando certa superioridade ao compará-la com a natureza. O uso da palavra mais, repetitivamente, deixa bem claro essa questão: que tinha os cabelos mais negros e mais longos, seu sorriso mais doce, seu hálito mais perfumado, seus pés mais rápidos. Iracema é muito mais que uma mulher, não anda, flutua. Toda a natureza rende-lhe homenagem[...]

Ela é filha de Araquém, Pajé da tribo Tabajara, e deve manter-se virgem porque "guarda o segredo de jurema e o mistério do sonho. Sua mão fabrica para o Pajé a bebida de Tupã." Mesmo tendo essa missão, ela luta contra todos para ficar com seu grande amor, Martim. Os valores foram rompidos, atinge o sagrado, a quebra do segredo, a perda da virgindade.

Iracema toma todas as iniciativas amorosas: “- Iracema te acompanhará guerreiro branco, porque ela já é tua esposa" (ALENCAR, 1999, p.56). 
Quando a índia vai atrás do seu grande amor, percebe-se que ela é uma mulher de atitude, é valente, está disposta a enfrentar tudo pelo seu desejo. Ela assume o lugar de protetora de Martim, planeja a fuga, traí a sua tribo. São perseguidos. Iracema não fraqueja nunca, ela luta ao lado de Martim contra a sua tribo e passa a morar com ele e o seu irmão Poti no litoral. "Iracema é rola que o caçador tirou do ninho" (ALENCAR, 1999, p. 102).

O que impressiona no perfil de Iracema é sentir como ela rompe com toda a tradição cultural de seu povo para seguir o guerreiro branco Martim. É como se a personagem ganhasse asas e num vôo esplêndido se libertasse do olhar do seu criador.

No perfil de Lúcia,

[...] tem traços psicológicos fortíssimos, o autor faz questão de colocar detalhes íntimos de sua memória [...] ela passa por uma experiência profunda que consideramos de extrema importância, mas vive a castidade na alma e no coração. Lúcia se debate entre o materialismo (dinheiro) [...] e a espiritualidade. [...] o lado material e espiritual entram em choque. (LIMA, 2006)

Uma das principais características é a contradição. Como Lúcia, ela tem o papel de cortesã sedutora, como Maria da Glória (seu nome de nascença) assume o papel de menina ingênua e simples.

Ela é capaz de sacrifícios e renúncias incríveis pelo bem estar de sua família, como a troca de identidade com a amiga morta para livrá-los da vergonha, por ela ter se entregado por dinheiro, mesmo que isso tenha acontecido por necessidade. Nesse momento, Lúcia tem um perfil heróico, que sobrepõe ao seu papel de cortesã.

Além de ser expulsa, acusada injustamente, a sua atitude é de independência para uma jovem criada nos padrões da época.

Maria da Glória é meu nome. Foi nossa Senhora, minha madrinha quem mo deu [...] Eu tive supremo alívio de comprar com a minha desgraça a vida de meus pais e de minha irmã [...] Nisto uma moça quase da minha idade veio a morar comigo [...] Lúcia morreu de tísica; quando veio o médico passar o atestado, troquei os nossos nomes. Meu pai leu no jornal o óbito de sua filha. (ALENCAR, 1987, p.109-112)

Alencar mostra que Lúcia é uma mulher forte, que se entrega à vida de cortesã para salvar sua família da doença e para educar à sua irmã, Ana. Ela vive atormentada pelo sentimento de culpa, porque a família representava um apoio moral e quando perde o apoio, ela sente muito, mas não se abate.

[...] A lua vinha assomando pelo cimo das montanhas fronteiras; descobri nessa ocasião, a alguns passos de mim, uma linda moça, que parara um instante para contemplar no horizonte as nuvens brancas esgarçadas sobre o céu azul e estreladas. Admirei-lhe do primeiro olhar um talhe esbelto e de suprema elegância [...] Ressumbrava na sua muda contemplação doce melancolia e não sei que laivos de tão 
ingênua castidade, que o meu olhar repousou calmo e sereno na mimosa aparição Que linda menina! Exclamei para o meu companheiro, que também admirava. Como deve ser pura a alma que mora naquele rosto mimoso! (ALENCAR, 1987, p. 13)

No fragmento acima, Paulo se embriaga com a beleza de Lúcia quando a vê pela primeira vez. São olhos de um homem que sente palpitar no coração um grande amor.

Quanto ao nome de Lúcia: "Como se trata de nomes, eu também proponho uma mudança, bocejou Rocinha. Em lugar de Lúcia, diga-se Lúcifer.” (ALENCAR, 1987, p.38)

Existe um trocadilho com o nome de Lúcia, o fragmento acima mostra o que há em comum Lúcia, a prostituta e Lúcifer, que lhe tira a graça divina e juntos lhe dão a capacidade de sedução, de perversão, de dominação.

Assim, Lúcia vai da sedução à inocência, mostrando-se ora como prostituta sensual e ora como donzela pura, ou seja, embora comercializasse o próprio corpo, ela ainda preservava a pureza que, por algumas circunstâncias, foi obrigada a deixar adormecida.

Nos fragmentos abaixo, pode-se ver Lúcia em atitudes de cortesã sedutora:

Lúcia ergueu a cabeça com orgulho satânico, e levantando-se de um salto, agarrou uma garrafa de champanha, quase cheia. Quando a pousou sobre a mesa, todo vinho tinha lhe passado pelos lábios [...] Lúcia saltava sobre a mesa. Arrancando uma palma de um dos jarros de flores, trançou-a nos cabelos [...] num requebro sensual, arqueou os braços e começou a imitar uma a uma as lascivas pinturas. (ALENCAR, 1987, p.42)

E Lúcia como uma menina casta e pura:

Uma ocasião, sentados no sofá, como estávamos à gola de seu roupão azul abriu-se com um movimento involuntário, deixando ver o contorno nascente de um seio branco e puro, que o meu olhar ardente devorou com ardente voluptuosidade. Acompanhando a direção desse olhar, ela enrubesceu como uma menina e fechou o roupão; mas doce e brandamente, sem nenhuma afetação pretensiosa. (ALENCAR, 1987, p.18)

Surge, então, Aurélia Camargo na sociedade do Rio de Janeiro. No fragmento abaixo, observa-se que a moça é diferente das mulheres de sua época, tem características marcantes, por onde passa, encanta a todos, principalmente aos rapazes que a disputam.

Há anos raiou no céu fluminense uma nova estrela. Desde o momento de sua ascensão ninguém lhe disputou o cetro; foi proclamada a rainha dos salões. Tornouse a deusa dos bailes; a musa dos poetas e o ídolo dos noivos em disponibilidade. Era rica e formosa. (ALENCAR, 1986, p.13).

É formosa e inteligente. É idealizada como uma rainha e heroína romântica pelo seu narrador: "régia fronte, coroada de diadema de cabelos castanhos [...]", "fada encantada [...]". 
O narrador acrescenta elementos que mudam o perfil de "mulher-anjo" e apresenta uma personagem mais humana, com traços realistas. Preocupada em mostrar à sua superioridade financeira e conseguir realizar o seu sonho.

A determinação e capacidade de dominação do caráter de Aurélia são claras nesse fragmento: "Desejo como é natural obter o que pretendo o mais barato possível; mas o essencial é obter; e, portanto até metade do que possuo, não faço questão do preço. É a minha felicidade que vou comprar" (ALENCAR, 1986, p. 28).

O personagem Senhor Lemos diz sobre o perfil de Aurélia: "Você é uma feiticeirinha Aurélia, faz de mim o que quer" (ALENCAR, 1986, p.26).

Aurélia sendo muito bela está sempre rodeada por adoradores, mas isso não a arrebata e, sim, causa grande indignação, o que fica estampado em seu rosto com expressões de desdém e decepção. Tem uma grande revolta pelo fato de a sociedade ser movida pelo interesse:

$\mathrm{Na}$ sala, cercada de adoradores, no meio das esplêndidas reverberações de sua beleza, Aurélia bem longe de inebriar-se da adoração produzida por sua formosura, e do culto que lhe rendiam, ao contrário parecia unicamente possuída de indignação por essa turba vil e abjeta. (ALENCAR, 1986, p.14)

Em outro momento da obra, nota-se a personalidade forte de Aurélia, mesmo a moça tendo um tutor, é ela, a heroína, quem decide suas ações como bem entende. Com essa atitude verifica-se mais claramente o tanto que seu perfil é incomum para a época em que vivia.

\begin{abstract}
Aurélia era órfã; tinha em sua companhia uma velha parenta, viúva, D.Firmina Mascarenhas que sempre a acompanhava na sociedade. Mas essa parenta não passava de mãe de encomenda, para condescender com os escrúpulos da sociedade brasileira, que naquele tempo ainda não tinha permitido a emancipação feminina. Guardando com a viúva as deferências devidas a idade, a moça não declinava um instante no firme propósito de governar sua casa e dirigir suas ações. (ALENCAR, 1986, p.13)
\end{abstract}

Com tudo isso, pode-se observar que Aurélia Camargo é uma mulher forte, dominadora, inteligente, bonita, possuidora de grande segurança a respeito das atitudes que quer tomar e não concordava com o fato do interesse pelo dinheiro mover a sociedade. É claro que nem todas as características incontáveis dessa "heroína" foram citadas, mas mostram o perfil dessa mulher especial.

Aurélia ora representa o lado romântico das mulheres que sempre estão à procura de um príncipe encantado [...] ora é caracterizada pelo narrador como a própria salamandra, lembrando a própria Eva, associada ao pecado e ao demônio, pela sedução que exercia sobre as personagens masculinas. Fugindo assim dos moldes da escola romântica, sendo capaz, inclusive, de pagar pelo homem que ama. (LIMA, 2006). 
Ao analisar os perfis das três personagens, concorda-se com o que Moisés (2001, p.144) ressalta: "Bem vistas às coisas, há pelo menos tanto realismo nas obras de Alencar [...] quanto na visão científica de Eça.”

São três protagonistas que dividem diferentes experiências de vida, mas suas personalidades se cruzam na busca pela libertação, seja ela financeira ou emocional.

Tanto Iracema, quanto Lúcia e Aurélia saem do domínio do olhar romântico do autor. É como se de repente elas tivessem asas e voassem além do contexto social da época em que estão inseridas.

Para Cereja; Magalhães (2003, p.251)

\begin{abstract}
A observação da produção literária dos escritores da última geração romântica, dos nos 1860-70, revela a existência de algumas tendências que apontavam cada vez mais para uma literatura voltada para seu tempo, o que caracterizaria o Realismo alguns anos depois. São exemplos dessas tendências a objetividade das descrições de certos romances e a denúncia de problemas sociais, como em Senhora e Lucíola. [...] Essas obras, em parte lá distanciadas de algumas posturas do Romantismo, como o exotismo, a fuga da realidade, o mal do século e outras, representam o início de um processo que culminaria numa forma diferente de sentir e ver a realidade, menos idealizada, mais verdadeira e crítica à perspectiva realista.
\end{abstract}

Assim, Alencar com a magia de um mestre mostra "sob vários aspectos, o romance romântico cheio de realismo, pois a ficção moderna se constitui justamente à medida que visou, cada vez mais, a comunicar ao leitor o sentimento da realidade, por meio da observação exata do mundo e dos seres." (CANDIDO, 1997, p.74)

"Alencar, autor que não trepidou em desmascarar convenções e pôr a nu certas idealizações da burguesia" (CANDIDO; CASTELLO, 1974, p.96), de repente retoma o seu olhar romântico e traz as personagens novamente, e as coloca no lugar que o romantismo as colocaria.

São três mulheres e três perfis. São personagens bem construídas. Iracema é forte, dona de sua vontade, mas se destrói doente de ciúmes e saudade de Martim, o grande amor de sua vida. É o ciúme que fala mais alto, é o medo de perdê-lo para outra, é o sentimento à flor da pele quando se deixa abater pelas dores do coração.

Lúcia representa a emancipação de mulher, troca seus sentimentos por dinheiro. Situase entre a sedução e a ingenuidade. Sedução, na comercialização de seu corpo, mas dentro de si, preservava a ingenuidade. Nesse conflito que se instala a única saída, ou o retorno ao romantismo, é buscar na tragédia da morte a solução ao pecado da prostituição.

Aurélia é o retrato da mulher que se rebela diante de uma traição, busca a vingança, faz uma crítica ao casamento burguês e à sociedade machista da época, apresenta uma temática realista, mas acaba dividida entre a razão e a emoção, deixa o amor falar mais alto, perdoando o amado. Assim, define as suas características de forma romântica (LIMA, 2006). 
“A arte romântica caracteriza-se pelo confessionalismo, pela revelação dos segredos mais íntimos da alma" (GOMES, 1992, p. 19).

As mulheres de Alencar, Iracema, Lúcia e Aurélia, não se limitaram às características de mulheres românticas, idealizadas, anjos e heroínas. Pois ao mudarem as próprias vidas, se tornam superiores e senhoras de atitudes universais. Logo, esse olhar esbarra no olhar romântico de um autor que, antes de tudo, soube traçar destinos que se confundiram entre o ficcional e o real, entre a razão e a emoção.

A fim de evitar uma margem muito grande de subjetividade neste trabalho inclui um questionário com vistas a um levantamento de dados sobre as personagens femininas Iracema, da obra Iracema; Lúcia, da obra Lucíola e Aurélia, da obra Senhora, de José de Alencar.

O questionário foi dirigido a alunos do curso de Letras da FFCL de Ituverava, com questões abertas para serem colhidos dados qualitativos.

Partindo do princípio de que seria impossível colher as informações de todos os alunos, foram distribuídos trinta questionários no mês de junho de 2008, nas diferentes salas e solicitado que no prazo de uma semana, respondessem e os retornassem às autoras. Após uma semana apenas doze alunos devolveram o questionário respondido.

A opção da aplicação do questionário a outros alunos do curso de Letras, leitores das obras de José de Alencar, teve a intenção de verificar outros olhares sobre um mesmo tema, negando ou confirmando o que se construiu a respeito dos perfis femininos.

Para a análise do questionário foram consideradas as respostas dadas, que foram transcritas da forma como foram respondidas pelos alunos.

No questionário não era obrigado a se identificar, por isso nem todos colocaram o nome. Assim, optou-se por preservar todas as identificações e usar os números de 1 a 12 para relacionar as respostas. Abaixo segue as questões com as devidas respostas e comentários.

Questão 1 - Você já leu as obras de José de Alencar?

\begin{tabular}{lccc}
\hline & LEITURAS & SIM & NÃO \\
\hline IRACEMA & 12 & 0 \\
LUCÍOLA & 10 & 2 \\
SENHORA & 10 & 2 \\
\hline
\end{tabular}

Nesta questão, verifica-se que dos doze alunos que responderam ao questionário todos são leitores das obras de José de Alencar. Todos já leram a obra Iracema, dez leram a obra Lucíola e 10 leram a obra Senhora. 
Questão 2 - Como você descreveria as personagens femininas?

Os doze responderam da seguinte forma:

IRACEMA:

1- Uma mulher forte, decidida que rompe os laços familiares para viver um grande amor.

2- Índia linda com grande sensualidade.

3- Jovem, bonita, forte e decidida a lutar pelo seu grande amor, mesmo que esse fato a separasse das pessoas que ela amava, de seus familiares e de sua tribo.

4- Uma jovem índia guerreira com muitos atributos femininos.

5- A virgem dos lábios de mel, valente, romântica, apaixonada.

6- Uma mulher capaz, apaixonadamente romântica, lutando pelos seus ideais e seus amores.

7- Personagem de vida primitiva era uma índia tida como a virgem dos lábios de mel e de cabelos mais negros que a asa da graúna.

8- Iracema, a virgem dos lábios de mel, uma mulher que vive na natureza, livre, onde seu comportamento às vezes é selvagem e outras vezes não. Iracema muda seu jeito de pensar e agir quando conhece Martim, seu amado.

9- Iracema, a virgem dos lábios de mel, com comportamento selvagem, ora sim ora não, tem uma mudança de comportamento ao se apaixonar.

10- Jovem bela, que vive na natureza, possui um comportamento selvagem e ao se apaixonar por Martim muda de comportamento e decide lutar pelo seu grande amor mesmo que isto a afastasse dos seus familiares.

11- Era uma jovem índia, guerreira e corajosa.

12- A personagem é uma índia idealizada, própria de uma obra romanesca. Tudo em Iracema é perfeito. Ela também é uma guerreira. Essa perfeição não existe se compararmos à realidade dos indígenas.

\section{LÚCIA:}

1- Aparentemente frágil, mas de uma fortaleza interior que rompe com os padrões familiares da época em que o homem era dono da verdade.

2- Mulher da vida, sensual, linda.

3- Não respondeu.

4- A vida obrigou-a a prostituir-se para poder se manter.

5- Sensual, provocante, cheia de vida e atitude. 
6- Uma mulher sensual, despojada de escrúpulos, liberal, conseguindo ser romântica, mesmo em um meio libertino.

7- Representou a vida burguesa no século passado, na situação familiar da mulher, lutou pelo amor e pela liberdade.

8- Lúcia, uma mulher da corte que quando se apaixona por Paulo começa a mudar de vida, tornando-se uma mulher leal e digna. Aceitava os presentes de todos os homens da corte menos o de Paulo, porque ela queria que ele a visse como uma simples mulher e não uma mulher da corte, que ganha a vida saindo com homens.

9- Mulher da corte real; quer ser tratada de forma diferente pelo homem amado; porém queria que ele a visse como uma mulher pura e delicada.

10- Mulher decidida e determinada imaginava que Paulo a visse como uma mulher pura e delicada.

11- Uma jovem que se viu obrigada a se prostituir para se manter.

12- Trata-se de uma prostituta, que não teve outra escolha de vida na sociedade em que vivia.

\section{AURÉLIA}

1- Autoritária, assume a direção de sua vida, humilha e vinga do seu amor, mas no final se redime.

2- Não respondeu.

3- Moça pobre torna-se rica graças à herança do avô; só é apresentada a sociedade aos 18 anos, onde encanta a todos com sua beleza. É independente e luta pela emancipação feminina, já que naquela época a sociedade tinha um grande preconceito contra o sexo feminino.

4- Conta a história de uma jovem chamada Aurélia, que ficou rica ao receber uma herança. Ela não ligava para o que a sociedade falava.

5- Decidida e inteligente.

6- Uma mulher independente, completamente inovadora para época, elegante e extremamente decidida, lutando pelos seus objetivos.

7- Bela, diferente das moças de sua época pela maneira de agir e pensar. Era educada e inteligente, corajosa e informada, inteligente e experiente.

8- Aurélia, uma mulher determinada a lutar pelos seus ideais, objetivo. Queria se vingar de Fernando por ter trocado seu amor por cem mil contos de réis. 
9- Aurélia, vingativa, ambiciosa, determinada, humilde. Luta pelo amor de Fernando; porém, engana-se, pois o dinheiro fala mais alto.

10- Determinada a lutar pelo amor de Fernando. Cheia de ódio e vingança, por causa de um amor ambicioso.

11- Uma jovem que ficou rica ao receber uma herança. Era autêntica e não se importava com a opinião dos outros.

12- Compra seu amado que era interessado em bens materiais, com isso consegue dominá-lo.

Das doze respostas sobre a descrição das personagens, percebe-se que quanto à Iracema, apenas cinco respostas a apontam como uma índia idealizada, apaixonada e própria representante do romantismo. Nas outras respostas, além de alguns expressarem esse pensamento, atribui-lhe também características como: uma índia forte, decidida, guerreira, que luta pelos seus ideais e pelo seu grande amor e que também muda de comportamento ao se apaixonar, não pensando duas vezes em abandonar todo o convencionalismo para viver com o seu amado.

Ao falarem de Lúcia, os onze leitores responderam unânimes que a personagem é uma pessoa forte, corajosa, linda, aparentemente frágil, prostituta, sensual, que lutou pelo seu amor e pela necessidade de se manter. Rompe com os padrões familiares da época em que o homem era dono da verdade.

Quanto à Aurélia, foram onze respostas considerando-a independente, autêntica, que sabe lutar pelos seus ideais, corajosa, inovadora, com poder de dominação sobre os outros, quando a sua vontade é maior e mais importante do que a própria natureza feminina.

Assim, os perfis já vão sendo delineados pelos alunos-leitores, como os perfis antes traçados e que apontam para uma mudança de caráter das personagens diante do maior impasse de suas vidas que é o de viver um grande amor. Se em pleno século XIX já era delineada essa nova mulher, hoje muito desses aspectos ainda estão presentes. Segundo Cademartori (1990, p.39) “A sensibilidade, a audácia, a anarquia e a sutileza da arte de hoje procedem da rebeldia romântica."

Questão 3 - Das três personagens, qual você achou mais feminina? Por quê?

1- Lúcia, pois valorizava a sua aparência e viveu mais intensamente o seu amor. Sofreu, mas deixou a emoção sobrepor a razão.

2- Lúcia, por causa do contexto mulher da vida. 
3- Iracema. Porque retrata o perfil da mulher brasileira.

4- Iracema por ser bonita, corajosa e romântica.

5- Não respondeu.

6- Iracema, devido ao modo.

7- Iracema.

8- Aurélia é uma moça delicada, humilde, sonhava que o amor vinha em primeiro lugar.

9- Lúcia, pois era como uma dama da noite; porém fazia-se de pura para alcançar seu objetivo: o homem amado.

10- Aurélia era humilde e queria se casar, inocente, achava que o amor estava acima de tudo.

11- Aurélia do livro Senhora, porque ela como muitas mulheres não querem aceitar o fato de amar alguém que sua consciência desaprova.

12- As três, cada uma em seu estilo próprio.

Nesta questão quatro responderam que Iracema é a mais feminina, enquanto que três acham Lúcia e outros três Aurélia. Um aluno não respondeu e outro disse que acha as três, cada uma no seu estilo. Algumas respostas foram um tanto vagas.

A questão da feminilidade das personagens alencarianas, é devidamente evidenciada no comentário de Candido (1997), ao falar sobre a influência da moda no romance, a íntima associação da moda com o próprio ritmo da vida social e a caracterização psicológica.

\footnotetext{
Alencar denota a influência da moda principalmente na intuição da vestimenta feminina, que aborda como elemento de revelação da vida interior: os vestidos de Lúcia, por exemplo, desde o discreto, de sarja gris, com que aparece na festa da Glória, até a chama de sedas vermelhas com que se envolve num momento de desesperada resolução, são tratados com expressivo discernimento. (CANDIDO, 1997, p.211)
}

Alencar, com sua capacidade artística consciente, revela que a desenvoltura aparente encobre um trabalho de detalhes e inspiração contrabalançada por boa reflexão crítica.

Em Senhora, Alencar apresenta Aurélia, dotada de uma inteligência superior à do irmão, com pensamento analítico para arquitetar seu plano de vingança, contrastando com os princípios religiosos da época, como também desprezo que nutre pela sociedade corrompida.

Talvez essa gama de valores antagônicos cause certa dificuldade aos leitores para perceberem de pronto a feminilidade latente na personagem que "era ligada aos valores morais, mas abandonava algumas convenções como o exigido recato feminino" (BORGES, 2008). 
Nas entrelinhas do romance Iracema, Alencar desenha a figura bela e poética da filha do Pajé da tribo dos Pitiguaras. Ele apresenta uma criatura copiada da natureza, e o leitor assiste embevecido, despontar o amor da heroína selvagem pelo homem civilizado.

\begin{abstract}
A pena do cantor d'O Guarani é feliz nas criações femininas; as mulheres dos seus livros trazem sempre um cunho de originalidade, de delicadeza, e de graça, que se nos gravam logo na memória e no coração. Iracema e da mesma família. Em poucas palavras, descreve o poeta a beleza física daquela Diana selvagem. Uma frase imaginosa e concisa, a um tempo, exprime tudo. (ASSIS, 1866)
\end{abstract}

Questão 4 - O que há de semelhança entre elas?

1- Três mulheres que rompem os padrões sociais, que lutam por seus amores e se fragilizam em nome dele.

2- A sensualidade, beleza, perfil feminino.

3- A luta pelos direitos femininos, para poder decidir sobre seus próprios destinos.

4- A sexualidade.

5- Todas são muito femininas.

6- Além de serem "as mulheres de Alencar", elas possuem uma extrema independência, porém valorizam muito que possuem, sendo verdadeiras guerreiras.

7- O poder de encanto, de serem exemplos verdadeiros de uma alma típica feminina, simbolizando a alma apaixonada.

8- O forte amor que ambas sentiam pela pessoa amada, e a luta para conseguir ficar ao lado do amado.

9- O sentimento e a luta pelo amor verdadeiro.

10- A intensidade no sentimento amoroso pelo amado.

11- Todas elas lutaram por amor.

12- Mulheres que lutam por seus ideais.

Todas as respostas falam da luta, do sentimento como algo capaz de mudar o próprio interior da alma feminina para expressar e lutar por um grande amor.

A semelhança entre elas reside no fato de que, "o bem e o mal perdem, praticamente, a conotação simples com que aparecem nos demais, cedendo lugar à humaníssima complexidade com que agem" (CANDIDO, 1997, p.209).

Alencar, dotado de grande romantismo, "parece mais senhor das suas capacidades criadoras nas situações mais dramaticamente contraditórias" (CANDIDO, 1997, p.206)

E é nessa atmosfera de contradições, que as três mulheres alencarianas se encontram 
Questão 5 - E de diferente?

1- Cada uma tem uma personalidade e vive uma situação singular.

2- O meio.

3- Aurélia é uma personagem urbana, enquanto que Iracema vive toda a simplicidade da natureza.

4- Iracema é personagem de um romance indianista e os outros são urbanos.

5- Cada uma delas possui um perfil.

6- O meio em que vivem.

7- Seus objetivos eram distintos.

8- A personalidade de cada uma delas em agir para lutar pelo seu amor.

9- A personalidade.

10- A personalidade.

11- Aurélia era independente financeiramente; Lúcia dependia do dinheiro de seus clientes e Iracema vivia do que a natureza fornecia.

12- A maneira que cada uma se porta e sua posição na sociedade.

De modo geral, o teor das respostas é coincidente, embora seja expresso de maneiras diferentes. Isso demonstra que os leitores estão atentos à capacidade de Alencar em mostrar as diferenças sociais que separam os amantes, mas a pureza de sentimentos acaba provocando a união final.

A questão da diferença de personalidade das personagens ficou evidenciada em cinco respostas, o que caracteriza a percepção de cada leitor em captar a alma feminina alencariana.

Alencar soube delinear cada perfil feminino com características semelhantes, porém, a diferença entre cada um reside num fator que dinamiza a obra de Alencar: "a desarmonia, o contraste duma situação, duma pessoa ou dum sentimento normal, e tido por isso como bom, com uma situação, pessoa ou sentimento discordante" (CANDIDO, 1997, p.208).

Questão 6 - Qual das personagens representa melhor as características do Romantismo? Por quê?

1- Iracema, porque seu individualismo e a sua insegurança a levam à morte.

2- Não respondeu.

3- Iracema. Porque toda a trama acontece em volta da natureza, sendo a natureza exaltada a todo o momento. 
4- Iracema, porque no Romantismo era falado do indianismo.

5- Iracema, porque ela é a personagem mais feminina e delicada.

6- Aurélia, pois Alencar usa recursos claros de uma realidade extremamente idealizada, tendo como desfecho um final feliz.

7- Iracema, porque enfocou o amor platônico, acontecimentos históricos nacionais, a morte e seus mistérios.

8- Iracema, porque seu amor era tão grande pelo Martim, que no final da obra ela acaba morrendo pelo forte amor que sentia pelo Martim.

9- Iracema, pois luta por seu amor até a morte.

10- Iracema, porque acontece na natureza sendo ela exaltada em toda trama.

11-Iracema, porque mostra a questão da virgindade e do amor impossível.

12-Iracema, por ser idealizada.

Das onze respostas obtidas dez afirmaram ser Iracema a que melhor representa as características do romantismo devido a sua idealização, o seu amor, a sua insegurança e a sua morte. Um aluno já considera a personagem Aurélia como a que melhor representa as características do romantismo, porque teve a realidade idealizada e um final feliz.

Ao mergulhar na vida em sociedade por meio de seus romances burgueses, Alencar tece "uma crítica emocional que só oferecia uma alternativa: o retorno ao índio, ao bandeirante, e a fuga para as solidões da floresta e do pampa" (BOSI, 2001, p.137)

Questão 7 - José de Alencar mostra certa constância no perfil feminino? Por quê?

1- Sim, porque os três perfis são de mulheres fortes, autoritárias, capazes de enfrentarem sem medo a vida, a família, a sociedade, mas amam e sofrem as conseqüências desse amor.

2- Sim, pelas características do autor, perfil do escritor.

3- Sim, porque todas as heroínas de Alencar protestam contra o casamento por conveniência, defendem o direito ao amor e à liberdade.

4- Não tem uma constância porque uma era índia, a outra garota de programa e a outra herdeira de uma fortuna.

5- Sim, pois todas elas sabem muito bem o que quer do começo ao fim do livro sem mudar de personalidade.

6- Sim. 
7- Porque Alencar é um apaixonado pela alma feminina, soube sentir, de fato, a plenitude amorosa para criar muitos de seus romances.

8- Não, porque cada uma das personagens tem um jeito, modo de pensar e perfil diferente uma das outras.

9- Sim, pois apesar de terem perfis diferentes, se assemelham no romantismo.

10-Sim, porque todas as personagens de Alencar defendem o direito ao amor e liberdade.

11-Sim, porque em todas as personagens femininas acima citadas eram mulheres românticas e sonhadoras.

12-Não respondeu.

Apenas um aluno não respondeu essa questão, enquanto que nove afirmaram que além da constância nos perfis femininos, eram mulheres românticas, mas que lutavam por seus direitos e sonhos. Dois responderam que não, porque cada uma tem a sua singularidade na forma de pensar e agir e vive uma situação diferente.

Os perfis femininos de Alencar não são tipos, são exceções, com maneiras próprias de reagir moralmente, que se tornam curiosos justamente pela originalidade do viver comum.

Assim, percebe-se pelas respostas, de modo geral, que não há uma só direção ao traçar os perfis, pois em determinada resposta ou pergunta o aluno aponta a personagem como essencialmente romântica, em outra questão já fala da sua luta, do poder de decisão sobre a vida, da fuga dos costumes da época e da independência que cada uma tinha. Isso vai ao encontro com a questão do realismo nas obras de Alencar (MOISÉS, 2001), ou com a forma diferente de sentir e ver a realidade, o que mostra certo grau de independência e menos idealismo (CEREJA, MAGALHÃES, 2003).

Quanto ao autor, fica claro o distanciamento das convenções e das idealizações românticas (CANDIDO, CASTELLO, 1974).

Alencar com seus perfis femininos permitiu ao público-leitor da época, feminino ou não, transportar-se para as páginas dos romances, espelharem-se nas heroínas, adornando-se dos dons em comum que possuíam. A ausência do medo de ferir a realidade e a coragem de transgredir as convenções sociais da época, tendo em vista, que por meio do romance é possível ultrapassar seus limites, assim como os heróis e heroínas e alcançar, com a capacidade peculiar de cada um, as realizações pessoais, em relação à luta por seus amores e ao sentido maior de suas vidas.

A aplicação do questionário contribuiu para que a análise tenha um caráter menos tendencioso, e também para observar as diferentes direções que existem, ao serem traçados os 
perfis femininos das personagens em estudo, ou seja, cada leitor tem sua forma de pensar e ver o mundo, assim como o autor é o criador do seu mundo ficcional.

A história cantada de Iracema, os amores devassos de Lúcia e a luta pela desafronta do amor ludibriado de Aurélia constituem três histórias, três perfis diferentes sob o mesmo olhar romântico.

\section{CONCLUSÃO}

O trabalho parte do significado de Literatura e do nascimento do Romantismo que se dá com o aparecimento da classe burguesa. Movimento que tem como traço marcante a idealização da mulher.

Assim, parte-se dessas reflexões para que se entenda o universo das personagens femininas do período romântico, que tem em José de Alencar um criador de tipos de mulheres, num contexto social diverso. São personagens como Iracema, Lúcia e Aurélia, das obras Iracema (1865), Lucíola (1862) e Senhora (1875), modelos que apresentam perfis muito interessantes e que também definiam os perfis femininos de uma época.

São três perfis de mulher, dialogando entre si, com valores morais e sociais, que estão inseridas em uma época em que a mulher pouca voz tinha na sociedade. Esses perfis têm um diálogo, por possuírem um mesmo objetivo, a determinação de mudar sua relação com a família e com a sociedade, em um contexto onde o sexo masculino é quem ditava as regras. Mas mesmo assim, não se deixaram dominar nem pelo meio nem pela família.

$\mathrm{Na}$ prosa de Alencar, criador de mulheres maravilhosas, contrapõe-se às situações vivenciadas com o sentimento das personagens.

Normalmente as heroínas românticas são moças sem opinião própria, obedientes às determinações dos pais, mulheres que não têm voz para decidir sua vida.

Enquanto que essas três personagens alçam vôo para além de sua época, saindo do domínio do olhar romântico do autor, quando mudam suas próprias vidas, demonstrando atitude de mulheres independentes, fortes, sem medo de nada e ninguém; não obedecem às determinações impostas pelo momento sócio-histórico de uma época.

Iracema luta contra todos e rompe com seus valores para ficar com seu amor. Ela descumpre com as leis do seu povo, não tem medo de ninguém, mostrando assim uma atitude de valentia.

Lúcia é portadora de fortes traços psicológicos, é capaz de grandes renúncias para salvar a família, tem um perfil heróico, independente, que foge dos padrões de sua época. 
Aurélia é uma moça diferente, dona de características marcantes, com a determinação e a capacidade de dominação, possui também poder de sedução sobre as personagens masculinas, capaz até de comprar o homem que ama.

Com essas características, observa-se que esses romances românticos por alguns momentos ficam dominados por certo realismo, fugindo assim, de seus padrões convencionais. Repentinamente, têm-se a impressão de que o autor se desperta desse vôo que faz na criação das personagens e as traz de volta, para o romantismo, à época a qual pertencem.

Iracema sente ciúme e insegurança por medo de perder o grande amor e acaba morrendo de desgosto e saudade; Lúcia encontra na tragédia da morte a solução para seus pecados; Aurélia mesmo comprando o seu amado, deixa dominar-se pelo sentimento e o perdoa.

Fica claro que essas personagens quase saem do contexto no qual se inserem quando o autor dá a elas qualidades de mulheres independentes, valentes, sedutoras; mas quando o amor fala mais alto que a razão ou a morte acontece para que os pecados sejam redimidos, alguns valores são resgatados por um escritor do romantismo que, por algum tempo, limitou o seu olhar.

Quanto ao questionário, a maioria das respostas aponta, Iracema como uma personagem idealizada, a que melhor representa as características do Romantismo e também a que possui maior feminilidade.

As respostas falam também que o traço mais comum entre as três é a luta pelo amor e, quase todos afirmam, que existe uma constância entre as personagens por serem mulheres românticas que lutam por seus direitos e sonhos. É muito pouco os que responderam sobre a falta de constância que cada uma tem na sua forma de agir e pensar.

Portanto, percebe-se que não existe uma só direção ao traçar os perfis, cada leitor, muitas vezes, é dono da sua leitura e tem na sua forma de pensar, a sua verdade.

Esses perfis femininos são exceções. São curiosos por serem ora originais, ora fugitivos do olhar comum de um autor e de sua época. Existe uma dicotomia no perfil dessas mulheres, ora são santas ora sedutoras, e é dessa forma que se delineou o nosso olhar para compreender os perfis de Iracema, Lúcia e Aurélia.

Alencar deu a essas mulheres atitudes que se distanciam da identidade ficcional e real das mulheres do século XIX, que em nenhum momento foram endeusadas. Elas sofreram, lutaram e ousaram, com a licença de um criador experiente, pelos seus desejos e prazeres, vitórias e derrotas, tão constantes em diversos momentos literários. 
São reflexões que propõe uma mudança de atitude dos leitores para que compreendam o universo feminino que, mesmo sob um olhar romântico, mostra mulheres guerreiras, independentes, apaixonadas, dispostas a mudarem seus destinos em nome do amor.

Assim, espera-se que esse olhar contribua para que outros olhares aconteçam nas leituras e releituras dessas obras e possam com isso instigar novos leitores.

\section{REFERÊNCIAS}

ALENCAR, J. M. de. Lucíola. 11 ed. São Paulo: Ática, 1987.

Iracema. 2 ed. Rio de Janeiro: Ediouro, 1999.

Senhora. 14 ed. São Paulo: Ática, 1986.

ASSIS, M. José de Alencar: Iracema. Publicado em 23 jan. 1866, na "Semana de Literária", seção do diário do Rio de Janeiro. Disponível em:

<http://pt.wikisource.org/wiki/Jos\%C3\%A9_de_Alencar:_Iracema> Acesso em: 9 out. 2008.

BORGES, V. R. Mulheres degeneradas. 01 fev. 2008. Disponível em:

$<\mathrm{http}$ ///www.revistadehistória.com.br/v2/home/?go=detalhe\&id=1407> Acesso: 9 out. 2008.

BOSI, A. História concisa da literatura brasileira. 32 ed. São Paulo: Cultrix, 2001.

CADEMARTORI, L. Períodos literários. 4 ed. São Paulo: Ática, 1990.

CANDIDO, A. Formação da literatura brasileira. Belo Horizonte/Rio de Janeiro: Itatiaia, 1997.

Formação da literatura brasileira. 6 ed. Belo Horizonte: Itatiaia, 2000.

Literatura e Sociedade. 6 ed. São Paulo: Nacional, 1980.

CANDIDO, A.; CASTELlO, J. A. Presença da Literatura Brasileira: História e Antologia. $10^{\mathrm{a}}$ ed. Rio de Janeiro: Betrand Brasil, v2, 1997.

CEREJA, W. R.; MAGALHÃES, T. C. Literatura brasileira. São Paulo: Atual, 1995.

Português: linguagens. São Paulo: Atual, 2003.

COUTINHO, A. A Literatura no Brasil: introdução geral. 5 ed. São Paulo: Global, 1999. v. 1.

A Literatura no Brasil: Era Romântica. 6. ed. São Paulo: Global, 2002. v. 3.

Notas de teoria literária. 31 out. 2006. Disponível em:

<http://recantodasletras.uol.com.br/teorialiteraria/278085> Acesso em: 30 set.2008. 
GOMES, A. C. A Estética romântica: textos doutrinários. São Paulo: Atlas, 1992.

GUINSBURG, J. Romantismo, historicismo e história. São Paulo: Perspectiva, 1978.

INFANTE, U. Curso de literatura de língua portuguesa. São Paulo: Scipione, 2001.

LEITÃO, E. V. A Mulher na língua do povo. Rio de Janeiro: Achiamé, 1981.

LIMA, M. E. M. de. Os conflitos da alma feminina, em Lucíola e Senhora, de José de Alencar. 21 dez. 2006. Disponível em: <http://pt.shvoong.com/books/473571-os-conflitosda-alma-feminina/>. Acesso em: 29 mar.2008.

MOISÉS, C. F. O Desconcerto do mundo do renascimento ao surrealismo. São Paulo: Escrituras, 2001.

POUND, E. Abc da literatura. São Paulo: Cultrix, 2007.

VENTURA, R. (1995) História crítica em Sílvio Romero. In: Mallard et alii. História da literatura: ensaios. 2 ed. Campinas: Unicamp. p. 37-54. 
